\title{
The first known grammar of (Kahenda-Mbaka) Kimbundu (Lisbon 1697) and Álvares' ars minor (Lisbon 1573)
}

Gonçalo Fernandes

\begin{abstract}
Pedro Dias, S.J. (1621/1622-1700) published the first known grammar book of Kimbundu, entitled Arte da Lingua de Angola, oeferecida (sic) a Virgem Senhora N[ossa] do Rosario, Mãy, e Senhora dos mesmos Pretos (Lisbon 1697) [Grammar of the Language of Angola, offered to our Virgin Mother of the Rosary, and Lady of the Negroes] for use by the Jesuit missionaries, particularly in the north-eastern of Brazil, to instruct and convert the several Angolan and other Bantu western African slaves living there. This paper describes Dias' grammar book relevance to the Portuguese, Brazilian and Angolan linguistic historiography. Dias' Arte, although a small book (only 48 pages) with no theoretical explanation, is a pioneering Bantu linguistic work, being the first known systematic grammar of (Kahenda-Mbaka) Kimbundu used as general or common language in Bahia and Rio de Janeiro, Brazil, in the $17^{\text {th }}$ century, and the second printed grammar of any Bantu language, preceded only by Vetralla's Regulae quaedam pro difficillimi Congensium idiomatis faciliori captu ad grammaticae normam (Rome 1659) [Some rules to better understand the most difficult language of the Congo people, using grammar norms]. This paper also demonstrates that the Arte da Lingua de Angola, in addition to the influence of Pacconio and Couto's catechism (1642), is based on Manuel Álvares' ars minor (Lisbon 1573), in spite of his ars maior (Lisbon 1572).
\end{abstract}

Keywords: Kimbundu; African slavery; Brazilian colonialism; Missionary Linguistics; Manuel Álvares (1526-1583) 


\section{Introduction}

Nowadays, it is commonly recognized that the Arte da Lingua de Angola, oeferecida (sic) a Virgem Senhora N[ossa] do Rosario, Mãy, e Senhora dos mesmos Pretos (Lisbon 1697) [Grammar of the Language of Angola, offered to our Virgin Mother of the Rosary, and Lady of the same Negroes]', written by Pedro Dias, S.J. (1621/1622-1700), was the first known grammar ${ }^{2}$ book of Kimbundu and the second printed grammar of any Bantu language, preceded only by the Regulae quaedam pro difficillimi Congensium idiomatis faciliori captu ad grammaticae normam (Rome 1659) [Some rules to better understand the most difficult language of the Congo people, using grammar norms] written by Giacinto Brusciotto a Vetralla (1601-1659). There are some references of a lost grammar and vocabulary (maybe in Kimbundu) by the Peruvian Lope de Castillo, S.J. (1595-ca.1668) entitled "Grammatica et Vocabularium Linguae Angolanae pro faciliori instructione Aethiopum, qui ex Africa, illuc tanquam mancipia deducuntur, ut in fide Christi erudiantur" or, in Spanish, "Grammatica y Vocabulario de la Lengua de Angola para poder instruir mas facilmente a los Negros que traen esclavos de Africa, en los Mysterios de la Fe", edited (handwritten or published) around 1680 (see, e.g., Homburger 1925:167; Maho 2009: 17; Streit \& Dindinger 1952: 845).

In 1954, Clement Martyn Doke (1893-1980) referred to Dias' book as a "meritorious piece of work" and "a remarkably accurate record of Ndongo" (Doke 1954: 11), which was unknown by later grammarians, such as the Italian Capuchin Bernardo Maria (Cassaro) da Canicattì (1749-1834), who "certainly has not profited from his work" (Doke 1954:11). Zwartjes, after analyzing the tense and verbal aspects in the early grammars of the Bantu languages, stated that "sin duda su descripción [de Dias] no tiene nada en común con la obra de Brusciotto" (Zwartjes 2009:256) [undoubtedly his description [of Dias] has nothing in common with the work of Brusciotto], and added that "the description of Tense Aspect Mood (TAM) in Dias's grammar is much more elaborate than that of Brusciotto" (Zwartjes 2011: 232).

However, if Dias did not know the work of Brusciotto a Vetralla, he knew the catechism of Francesco Pacconio ${ }^{3}$ (1589-1641), entitled Gentio de Angola sufficientemente instruido nos mysterios de nossa sancta Fé [A Gentile of Angola

1. The author of this paper did all translations into English.

2. The term 'grammar' is a polysemic word, and linguists use it in various senses. In summary, the main use today amongst linguists is to describe a linguistic theory or a systematic or scientific study of a language, e.g., the functional and the (transformational) generative grammar. However, it can also mean a physical book written by a grammarian, which describes the rules of a language's structure, implicitly known by native speakers. Additionally, the term can be used as a synonym for the descriptive grammar of a language, which explains a language as it is used by speakers (linguists), or as the prescriptive grammar, which defines the 'correct' or the 'incorrect' use of a language (grammarians), in order to write and speak the language correctly. In this case, I use the term to denote physical grammar books, be they descriptive or prescriptive in intention.

3. Francesco Pacconio was born in Capoue, Italy in 1589, entered the Society of Jesus in 1607, studied grammar and humanities, lived in African west kingdoms for 24 years, and returned to Lisbon in 1641, where he died on November 13, 1641. 
sufficiently instructed in the mysteries of our holy Faith], published posthumously in Lisbon in 1642 by António do Couto (1614-1666) (pp. 9 and 34). Actually, Pacconio did not write a grammar book but he preceded his catechism with the prologue of "Advertencias para se ler a lingua de Angola" [Warnings on how to read the Angolan Language], which greatly facilitated the understanding of Dias' text concerning the orthography (Rosa 2006: 208-209).

Thus, in this paper I will try to show the relevance of Dias' grammar book to the Portuguese, Angolan and Brazilian historiography. I will attempt to demonstrate that Dias' Arte is a pioneering Bantu linguistic work, being the first known systematic description of (Kahenda-Mbaka) Kimbundu used as general language in Bahia and Rio de Janeiro, Brazil, in the $17^{\text {th }}$ century. I will analyze some of Dias' linguistic ideas, particularly his understanding of 'the language of Angola', its pronunciation, and his main sources. The paper will be divided into three main chapters. In the first, I will present some preliminary historical data about the author and the Jesuits in Brazil in the $17^{\text {th }}$ century. In the second, I will analyze Dias' Arte, divided into two sections. Here, I will assess what Dias wanted to say with the expression 'language of Angola' and in the second section, I will offer some questions concerning its specific pronunciation. Lastly, in the third chapter I will explicitly analyze the influence of Manuel Álvares' (1526-1583) De institutione grammatica libri tres, trying to prove that Dias'Arte was based on his ars minor (Álvares 1573), in spite of his ars maior (Álvares 1572).

\section{Pedro Dias}

Pedro Dias was a Portuguese Jesuit missionary in Brazil in the $17^{\text {th }}$ century. He was born in Gouveia, in the District of Guarda, Portugal. According to Leite (1947: 11), Dias died on January 25, 1700, at the age of 79. Thus, he must have been born in 1621 or no later than early January 1622 . However, we need more documentary evidence ${ }^{5}$ to definitively sort out this issue. Dias' parents immigrated to Brazil with their son at a very tender age, and he joined the Society of Jesus in the College of Rio de Janeiro at the age of only 19, on July 13, 1641 (Leite 1947: 9). For Bonvini (2008: 35-36), this was an important date in the history of the Angola and of the Jesuits in Brazil:

O contexto histórico de 1641 não é anódino. Se esse ano coincide com a ocupação de Luanda pelos holandeses, que a consideravam o melhor mercado de escravos do mundo, no Brasil ele sucede a um ano de perturbações, tanto no Rio como em Santos e em São Paulo, que ocorrem depois da publicação do Breve do Papa Urbano VIII a respeito da liberdade dos ameríndios. Em 1640, revoltas antijesuíticas tiveram

4. The Jesuit António do Couto (1614-1666) was born in Luanda, Angola, on January 1, 1614 , entered the Society of Jesus in 1631, worked in S. Salvador do Congo college (currently Angola) of which he was the rector during two decades, and died in Angola on July 10, 1666 (See Rodrigues 1931-1950, tome III, vol. II: 368; Brásio 1952-1988, XI: 100-101 and XIII: 249).

5. I could not find the birth registration of Pedro Dias at the Archive of District of Guarda nor at the Archive of Torre do Tombo, in Lisbon. 
lugar no Rio de Janeiro (...). Um episódio, nelas ocorrido, significativo para nosso propósito, é assim evocado: «O populacho criticou acerbamente os jesuítas por possuírem mais de seiscentos escravos só em um colégio do Rio, mas os padres procuraram justificar-se alegando que os escravos 'eram quase todos negros'» (Boxer 1973: 147) (Bonvini 2008: 35-36).

[The historical context of 1641 is not trivial. If this year coincides with the occupation of Luanda by the Dutch, who considered it the best slave market in the world, in Brazil, it follows a year of disruption, both in Rio, Santos and São Paulo. All of which occurs after the publication of the Brief by Pope Urban VIII regarding the freedom of the Amerindians. In 1640, revolts against Jesuits took place in Rio de Janeiro (...). One episode, having occurred in a significant way for our purposes, is mentioned as follows: "The populace bitterly criticized the Jesuits for owning more than six hundred slaves in just one Rio College, but the priests sought to justify themselves, arguing that the slaves 'were almost all blacks"' (Boxer 1973: 147).]

For the Historian of the Society of Jesus in Brazil, Serafim Leite, S.J. (1890-1969), Pedro Dias professed, in Rio de Janeiro, the first three Jesuit solemn vows in 1660 and the fourth in 1679. He studied civil law, canon law and medicine, which was important to care for the poor and the African slaves, mainly when pestilential disease occurred (yellow fever) in Pernambuco between 1685 and 1694. He was the Superior of the Jesuit House of Porto Seguro (4 years), Rector of the College of Santos (3 years), Prosecutor in the sugar mills (for a few years) and Rector of the Jesuit College in Olinda, Pernambuco (6 years) (Leite 1947: 9-10). Dias died in the Jesuit College of Bahia on January 25, 1700.

Also according to Leite, he was so gentle and careful with the black people that the African slaves celebrated his death devotedly (Leite 1947: 10) and they asked the General Governor of Brazil the honor of conducting him to the tomb (Leite 1938-1950, VIII: 199). He received the nickname "Apostle of the Black People” (Leite 1938-1950, VIII: 199; 1965: 220; 1993: 220).

\section{The Arte da Lingua de Angola}

The Arte da Lingua de Angola by Pedro Dias was published in Lisbon, ${ }^{6}$ Portugal, in 1697, by Miguel Deslandes ${ }^{7}$ (?-1703), and it has only 48 pages in format $8^{\circ}$. It was written in Portuguese with examples (seemingly) in Kimbundu in the College of

6. Dias' Arte could not have been printed outside Portugal because there was no printing authorization in any of its colonies, with exceptions for Asia. Outside Portugal, typography first arrived in Goa, India (1556), then in Macau, China (1584-1588), and finally in Kazusa, Japan (1591) (Assunção 2011: 95). In Brazil, official printing offices only became a reality in the beginning of the 19th century when the Portuguese royal family moved into Rio de Janeiro with the founding of the Impressão Regia [Royal Press] by decree on May 13, 1808. In the African colonies, they started printing only in the middle of the 19th century: Cape Verde in 1842; Angola in 1845; and Mozambique in 1854.

7. The printer Michel Deslandes was born in Thouars, France, settled in Lisbon, Portugal, in 1669, and was naturalized Portuguese in 1684. After the death of António de Melo Craesbeeck in 1687, he was nominated the Portuguese "Royal Printer". He died in Lisbon in 1703 . 
Bahia (Bonvini 2009: 18-19), which was at that time the most important Brazilian Jesuit college and "permanece para a posteridade o mais alto padrão dos estudos gerais no Brasil" (Leite 1993: 50) [it remains for years to come to be the highest standard of general education in Brazil].

Leite presented the contents of an important letter written by Dias, in Bahia, on August 3, 1694, to the 13th Superior General of the Society of Jesus, Tirso González de Santalla (1624-1705), in which he spoke of his book and two vocabularies ${ }^{8}$ of the Angolan language he was preparing:

Diz que concluiu a Arte da Língua de Angola, movido pela necessidade espiritual em que jazem os angolanos. Compô-la segundo as regras da gramática e foi revista e aprovada pelo P. ${ }^{\text {e }}$ Miguel Cardoso, natural de Angola, muito versado nessa língua, e a manda agora o Provincial para se imprimir, pedindo ao Geral a indispensável licença. Estão à espera dela muitos novos e até velhos, que trabalham com estes miserabilíssimos e ignorantíssimos homens, e não se acha nenhuma Gramática desta língua, nem no Brasil nem no Reino de Angola. Tinha também começado um Vocabolário Português-Angolano; e logo que o concluir vai compor o Vocabolário Angolano-Português. Assim se acabará a dificuldade em aprender esta língua (Leite 1947: 10).

[It says that [he] finished the Art of the Language of Angola, inspired by the spiritual needs in which the Angolans are found. He composed it according to the norms of grammar and it was reviewed and approved by Father Miguel Cardoso, who was an Angola natural, well versed in the language, and then sent it to the Provincial to print and then asking the General for the necessary license. Many young and even older [missionaries] that were working with these most miserable and most ignorant men were waiting for it, as no grammar for this language could be found either in Brazil or in the kingdom of Angola. He had also begun a Portuguese-Angolan Vocabulary, and, once it will be finished, he will compose the Angolan-Portuguese Vocabulary. Thus, the difficulty in learning this language will end.]

As mentioned, Dias' Arte consists of 48 pages (excluding cover sheet and authorizations). Without any theoretical explanation, it describes the most relevant aspects of Angolan language and presents some orthoepic and orthographic indications about this language; morphology [nominatives (4-8), relative pronouns (9-10), demonstrative nouns (10), verbal conjugations (11-21), negative verbs (21-22), substantive verbs (22), defective or imperfect verbs (23), genders (23-24), past tenses (24-27), past perfect tenses (28-31), verbal noun compositions (31-32), augmentatives (32-33)], and syntax rules [rules of nominatives (33), infinitive verbs (35), adjective nouns (35-37), relative pronouns (37-39), substantive continuous (39), processes of forming questions and answers (39-40), genitive case (40), partitives (40), superlatives (41), neutral verbs (41-42), active verbs (42-43),

8. Unfortunately, I do not know if Dias finished the Vocabolário Português-Angolano [Portuguese-Angolan Vocabulary] nor even if he started the Vocabolário Angolano-Português [Angolan-Portuguese Vocabulary]. I have no other useful information about these two dictionaries. 
datives and accusatives (43), ablative verbs (43), passive verbs (43), locatives or “propria pagorum" (43-44), gerunds (45), adverbs (45-47), interjections (47), and conjunctions (47-48)].

Recently published linguistic studies have examined the pioneering nature of Dias work, although he had affirmed in his letter to the Superior General of the Company of Jesus that he had written the book "segundo as regras da gramática" (quoted by Leite 1947: 10) [according to the norms of the [Latin] grammar]. Zwartjes (2011: 224-235), for example, analyzed in detail Dias' concepts of phonology and orthography and the main aspects of his Kimbundu morphosyntax (nominal and verbal morphology). For instance, in the chapter "Dos nominativos" [Of the nominatives], he stated that the "language of Angola" has neither declension nor cases (Dias 1697: 4). He corroborated the same argument in the chapter on personal pronouns (Dias 1697: 8), and on questions and answers (Dias 1697: 39). He also indicated that this language has no passive voice, which is constructed using the active verbs and certain particles before the verb (Dias 1697: 22). In regards to gender, Dias also said that this language has no gender, but that it is specified by certain words, such as "male" or "female" (Dias 1697: 23-24). Dias did not realize that (Kahenda-Mbaka) Kimbundu was a prefixal language, but, when comparing with the Portuguese syntax, he found a similar construction. For example, in the case of the partitives:

Servem de partitivos as particulas $B o, M o$, com advertencia que quando no Portuguez dizemos dos, das, de, poremos a particula Bo. v.g. Boyuma yâ yé nguami nequimoxi. Das vossas cousas naõ quero nem hũa só. Moyâma yosso onzamba yâ beta ocusuîna, entre todos os animaes o elefante he mais forçoso. O exẽplo está em $b o$, antes do nome yûma, \& em mo, antes do nome yâma (Dias 1697: 40).

[The particles $B o, M o$, serve as partitives, with the qualification that when we say in Portuguese, dos, das, de, we put the particle Bo. e.g., Boyuma yâ yé nguami nequimoxi. I do not want any of your things. Moyâma yosso onzamba yâ beta ocusuîna, the elephant is the strongest amongst all animals. The example is in $b o$, before the name yuma, and in $m o$, before the name yâma.]

\subsection{The 'Language of Angola'}

The Swiss Protestant missionary Héli Chatelain (1851-1908) was the first scholar who classified the language described in Dias' Arte as Kimbundu and observed that the author, despite some limitations, had an understanding of the mechanism of the language and some of his observations were perfectly correct:

A primeira obra puramente grammatical sobre o kimbundu foi a «Arte da língua de Angola, oferecida á Virgem Senhora nossa do Rosario, Mãy e Senhora dos mesmos pretos, pelo P. Pedro Dias, da Companhia de Jesus. Lisboa. Na officina de Miguel Deslandes, impressor de S[ua]. M[ajestade]. Com todas as licenças. Anno 1697». Este livrinho era já tão raro nos fins do seculo passado que Cannecattim não teve conhecimento d'elle. Conhecemol-o nós por uma copia manuscripta que o Sr. Dr. Alfredo Troni de Loanda nos fez o obsequio de nos emprestar na véspera do nosso embarque para a Europa. Este trabalho desenvolve e completa as «regras brevissimas» 
que accompanham o Catechismo, do qual também são tirados os exemplos que devem elucidar as regras. Estas, comquanto não primem pela correcção do portuguez, nem pela propriedade da terminologia, provam, no emtanto, que o auctor entendia o mechanismo do kimbundu. No que diz respeito ao dialecto particular do Catechismo são, salvo poucas excepções, perfeitamente correctas. É provavel que o opúsculo foi escrito no Brazil, visto que a primeira licença é datada da Bahia, 13 de junho 1696..... e a oitava e ultima do Paço, Lisboa, 9 de agosto 1697 (Chatelain 1889: xvi).

[The first purely grammatical work of Kimbundu was the "Grammar of the Language of Angola, offered to our Virgin Mother of the Rosary, and Lady of the same Negroes, by Priest Pedro Dias of the Company of Jesus. Lisbon. In the printing office of Miguel Deslandes, printer of His Majesty. With all licenses. Year 1697'. This little book was so rare by the end of last century that Cannecatim was not aware of it. We know it through a manuscript copy that Mr. Dr. Alfredo Troni of Luanda kindly lent to us the day before our departure for Europe. This work develops and completes the "briefest rules", which accompany the Catechism, from which examples are taken, that should clarify the rules. These, although they do not stand for the correctness of Portuguese or for the adequacy of terminology, prove that the author understood the mechanism of Kimbundu. Regarding the particular dialect of the Catechism, with few exceptions, it is completely correct. It is probable that the booklet was written in Brazil, considering that the first license is from Bahia, dated June 13, 1696...and the eighth and last, from the [Episcopal] Palace, in Lisbon, dated August 9, 1697.]

However, in the entire book, Dias never referred to the language described in terms of 'Kimbundu', but always as "lingua de Angola" [language of Angola] (twice: title and page 1), "lingua angolana" [Angolan language] (twice: pp. 10 and 33), "lingua ambunda" [Mbundu language] (once: page 17), "lingua dos Ambundos" [language of the Mbundu] (thirteen occurrences: pp. 10, 22, 33 (twice), 39, 40, 41, 42, 43, 44, 46 (twice), and 47) and some neutral expressions, like "esta lingua" [this language] (four times: pp. 1, 4, 22 and 23), "desta lingua" [of this language] (once: page 24) and "nesta linga" [in this language] (seven times: pp. 29, 33, 34, $35,41,44$ and 47). It is important to highlight that the noun "Angola" does not refer to the contemporary geopolitical term, the country known as the current Republic of Angola. As Rosa (2013: 32-34) showed, the borders of the Republic of Angola were set after the 1884-85 Berlin Conference. At the end of the seventeenth century, "Angola" signified the northwest part of present-day Republic of Angola and part of southwest Democratic Republic of Congo, which means the kingdom of the Ngola inhabited by the Mbundu people who spoke Kimbundu. ${ }^{9}$ In 1891, Ladislau Batalha (1856-1939) had already said:

Por três nomes ella tem sido tratada na Europa: Nbundo, Umbundo e Quimbundo. Só este último é verdadeiro, embora Heli Chatelain fôsse o primeiro a reconhecel-o. Effectivamente tivemos accasião de ouvir dos indigenas uma phrase, entre elles

9. Kimbundu is an agglutinative Niger-Congo language from the Bantu group, also known as Dongo, Kimbundo, Kindongo, Loanda Mbundu, Loande, Luanda, Mbundu, N'bundo, Nbundu, Ndongo, or North Mbundu. It is spoken currently by more than 4,000,000 people in the Northwest of Angola, mainly in the Province of Luanda (see Lewis, Simons \& Fennig 2014). 
proverbial, que mostra bem a distinção apresentada pelo philologo suisso: $O$ nbundo zuela kimbundo, isto é, o filho do paiz (o natural, o indigena), fala kimbundo (no sentido em que nós aplicamos: falar portuguez, ser claro, pão pão, queijo queijo, e outros dizeres) (Batalha 1891: 8).

[In Europe the language has been called by three names: Nbundu, Umbundu and Kimbundu. Only the last one is authentic, though Heli Chatelain was the first to recognize it. Indeed, we had the opportunity to hear one sentence of the natives, a proverbial phrase amongst them, clearly showing the distinction presented by the Swiss philologist: $O$ nbundo zuela kimbundo, that is, the son of the country (the natural, the indigenous), speaks Kimbundu (in the sense that we apply: to speak Portuguese, to be clear, bread bread, cheese cheese, and other words).]

Levi stated that "the generic title 'lingua de Angola' should be read as 'língua Kimbundu', given that the Arte is in fact a grammar of Kimbundu" (Levi 2009: 383). On the other hand, Zwartjes inferred that Kimbundu described by Dias, as in Pacconio's catechism, was probably, a different variety from the spoken dialect of Luanda or of the Backlands, in the interior of Angola: "As Chatelain (...) observes, the Kimbundu language used in Pacconio's catechism is not exactly the same variety as the language spoken in Luanda, not that of Ambaca, but possibly the dialect spoken in the mission of Cabinda (sic) in the district of Ambaca." (Zwartjes 2011: 222) Cabinda is clearly a mistake. Zwartjes meant "Cahenda", as it was used by Chatelain (1889: XVI): “O dialecto em que está escrito não é o moderno de Loanda, nem exactamente o d'Ambaca; será talvez o que se fallava no século XVII na missão de Cahenda (concelho de Ambaca)" [The dialect in which this is written is not modern Luanda, nor exactly from Ambaca. Most likely it is what was spoken in the $17^{\text {th }}$ century in the mission of Cahenda (municipality of Ambaca)]. There is, nevertheless, no proof of the existence of a Jesuit mission at Cahenda, but a Capuchin college (see, e.g., Bortolami 2012: 104; Azevedo 2000: 56). The Historian of the Society of Jesuits in Angola, António Brásio, S.J. (1906-1985), did not refer to any Jesuit college or permanent settlement there. However, in the 19th century, David Livingstone (1813-1873) spoke of the missionary station of Cahenda and the work of the Jesuits and Capuchins:

Some ten or twelve miles to the north of the village of Ambaca, there once stood the missionary station of Cahenda, and it is now quite astonishing to observe the great numbers who can read and write in this district. This is the fruit of the labours of the Jesuit and Capuchin missionaries, for they taught the people of Ambaca; and ever since the expulsion of the teachers by the Marquis of Pombal, the natives have continued to teach each other (Livingstone 1984 [1857]: 382).

An integrated research team of Brazilian and Angolan Bantuists currently studies the nine Kimbundu dialects (Dembo, Jinga, Kadi, Lwangu, Mbaka, Mbamba, Ntemo, Puna and Sende) and they have concluded that the language described in Dias' Arte (as well in Pacconio's catechism) is the Kahenda sub-dialect of the Mbaka dialect, spoken in the suburbs of the Jesuit Cahenda Mission, located near the municipality of Ambaka (named Camabatela before 1975), in the district of Kwanza North, between Bengo and Malange districts in Angola (Angenot, Kempf \& Kukanda 2011: 233). 
Despite the fact that Dias had never been in Angola, Miguel Cardoso, S.J.(1659-1721), who supervised the book, was born in Angola. Serafim Leite (1940: 258) stated that Miguel Cardoso was born in Luanda and entered in the Jesuit order in Brazil, in the Bahia College, in 1674, when he was 15 years old. Therefore, it is unlikely that he spoke the Kahenda-Mbaka subdialect, but most likely, the Akwa-Loanda dialect, spoken in Luanda in the $17^{\text {th }}$ century. Furthermore, in that period, there was also an important social group of Portuguese-Africans (later called Ambakists), who not only were saved from the slave trade, but who became the most efficient slave traders. These "Ambakists" were taught in the Cahenda Mission and they spoke the Kahenda-Mbaka dialect. Thus, it is possible that the Jesuits may have used pedagogically (or perhaps they imposed) the Kahenda-Mbaka subdialect of Kimbundu as a general or common language in Brazil (in Rio de Janeiro and in Salvador of Bahia) in the $17^{\text {th }}$ century, for instructing and converting the Angolan slaves and other Bantu ethnic groups (Angenot, Kempf \& Kukanda 2011: 233-235). More studies are needed to confirm or deny this hypothesis. Although, it is important to emphasize, as Bonvini (2008: 38) said that “(...) se trata de uma língua em sua integralidade, próxima da que é falada atualmente em Angola. Não se trata, de maneira nenhuma, de um pidgin ou de uma língua mista" [ . . it is a whole language, close to what is actually spoken in Angola today. It is not, indeed, a pidgin or a mixed language]. Dias had already admitted having found varieties, motivated perhaps by the different origins and nations of the Angolan people:

Tem os verbos desta lingua geralmente tres preteritos perfeitos; o 1. significa ha pouco tempo; o 2. que ha mais tempo; o 3. que ha muito mais tempo. Porèm tem-se por experiencia que algũas vezes usaõ hum por outro; deve ser pela variedade das terras, \& nações (Dias 1697: 24).

[The verbs of this language usually have three perfect tenses; the 1st means a short time ago; the 2nd longer ago; the 3rd much longer ago. But it has been my experience that they sometimes use one by another; this should be due to the variety of lands, and nations.]

\subsection{The pronunciation of (Kahenda-Mbaka)}

A problem was recently raised concerning the question of Latin phonetics by Carlota Rosa (2006) who referred to the Kimbundu phonetics presented by Dias. In the "Advertencias de como se hade ler, \& escrever esta Lingua" [Warnings on how to read and write this Language], Dias stated that "o Pronunciar, \& escrever he como na lingua Latina" (Dias 1697: 1) [Pronouncing and writing is similar to the Latin language]. This statement should not have, supposedly, caused any trouble, especially at a time when Latin was the common language or lingua franca amongst the Jesuits and the missionaries, the potential readers of the book, who had a deep classical education. The difficulty was that the language of communication was written Latin, and not, supposedly, the spoken Latin in day-to-day conversations. In effect, there are at least three types of pronunciation of Latin, and I cannot determine which one Dias was referring to: the traditional Portuguese, the traditional Italian, i.e., the official Catholic Church, or the restored classical pronunciation established in the Renaissance. Rosa (2006: 215) stated that "o produto de tantas pronúncias 
locais para o latim somado a diversas tentativas de fixação de pronúncias reformadas levou ao paradoxo de ter-se uma língua de comunicação internacional que nem sempre podia ser compreendida se empregada fora da terra natal daquele que a falava" [The product of having so many local pronunciations of Latin, added to the several attempts to fix reformed pronunciations, led to the paradox of having a language of international communication, which could not always be understood if employed outside the speaker's country of origin].

Exemplifying this difficulty, Dias said that Kimbundu "naõ tem $R$ dobrado, nem no principio do nome, nem no meyo, v.g. Rierino, hoje: Rimi, lingua" (Dias 1697: 1) [(Kimbundu) has no doubled $R$, not in the beginning, not in the middle of the name, v.g. Rierino, today, Rimi, language]. This means that in Kimbundu there was no phonological opposition between the single alveolar vibrant allophone [r] and the multiple alveolar vibrant allophone or trill $[\mathbf{r}]$, which is why there seems to have been no reason to write the initial or medial digraph $<$ rr $>$, "rrierrino ou *rrimi.

Another complexity in understanding Dias' view of Kimbundu pronunciation, due to the use of the Latin alphabet and the lack of distinction between letter and sound, e.g., grapheme-phoneme, has to do with the succession of plosive consonant and pre-nasal fricative: "As letras seguintes, $B, D, G, V, Z$, se the poem antes a letra $N$, v.g. Nburi, carneiro. Ndungue, traças. Ngombe, boy. Nvula, chuva. Nzambi, Deos" (Dias 1697: 1) [The following letters $B, D, G, V, Z$ are put before the letter $N$, e.g., Nburi, lamb. Ndungue, moths, Ngombe, bull, Nvula, rain. Nzambi, God]. In both cases, we find the clarification or part of it, in Pacconio \& Couto's catechism (1642). In the first, the explanation for the pronunciation of the " $r$ " (the single alveolar vibrant allophone), is found in the two examples in Portuguese, marisco [shellfish] and marinho [marine]:

Nunca dobram a letra, $R$, ou seja, no principio do nome, ou no meyo. Exemplo, Ririmi, lingua, Ritui, orelha, Rigimbuluilo, declaraçam: por onde se achar nome, que comece por, $R$, não se dobrarà tal letra, mas pronunciarseà como a penultima de marisco, marinho, \&c. (Pacconio \& Couto 1642: [XIV-XV]).

[They never duplicate the letter $R$, that is, in the beginning, or in the middle of the name. For example, Ririmi, language, Ritui, ear, Rigimbuluilo, statement: where a name that starts with $R$ is found, the said letter is duplicated, but it is pronounced like the penultimate consonant of marisco [shellfish], marinho [marine], etc.]

In the second case, Pacconio stated that the native language of Brazil has the same prenasalized consonants, such as in the examples nde [you] and ndaeteè [thus, I]:

De ordinario os nomes, ou verbos que começam nestas letras, $B, D, G, V$, consoante, $\& Z$ se lhes poem hũa letra $\mathrm{N}$, antes porque na pronunciaçam mostram, que requerem este $N$ Exemplo. Nbondo, hũa certa arvore, Nburi, cabrito, Ndungue, traças, Ndui, Azagaia, Ngana, Senhor, Ngombe, boy. Nvula, chuva, Nvunda, briga. Nzambi, Deos. Nzamba, elephante. \& caet. E também na lingua do Brasil se acha esta pronunciaçaõ. Exemplo. Nde, id est tu, Ndaeteè, por isso eu (Pacconio \& Couto 1642: [XV]).

[Ordinary nouns or verbs that begin with the letters, $B, D, G, V$, consonant, and $Z$ are preceded by the letter $N$, because in pronunciation they show that they require this $N$. 
Examples of this are; Nbondo, a certain tree, Nburi, goatling, Ndungue, bookworm, Ndui, javelin, Ngana, Sir, Ngombe, bull, Nvula, rain, Nvunda, fight, Nzambi, God, Nzamba, elephant, etc. This pronunciation can also be found in the Brazilian language. For example: Nde, id est You. Ndaeteè, thus I.]

On the other hand, it is clear that Dias did not know the second edition of the Gentio de Angola (Rome 1661), published by the Italian Antonio Maria of Monte Prandone, O.F.M. (1607-1687) ${ }^{10}$, which could have helped Dias in the Kimbundu phonetics. The 1661 edition is not the only Latin translation of Pacconio and Couto's catechism. Monte Prandone added some linguistic observations (besides new several Latin Catholic sermons). For example, in the "Observationes in legendo idiomate Angollae" [Observations on reading the Angolan language] ${ }^{11}$, Monte Prandone inserted a new "observation", the (new) number nine: "Hae syllabae anha, anhe pronunciantur, vt pronunciaretur apud Italos, ana, ane. Item ge, gi pronunciantur vt ghe, ghi. Item chi, cho faciunt ci, cio" (Pacconio \& Monte Prandone 1661: XV) [These syllables anha, anhe are pronounced like the Italian ana and ane. Ge, gi are pronounced like ghe and ghi. Chi, cho make $c i$ and ciò]. In other cases, Monte Prandone inserted Latin or Italian pronunciation. Particularly interesting is the supplement of two pages (104-105), at the end of the catechism, with pronouns, numerals and the "cases" of article for nouns. However, in opposition to Dias, Monte Prandone believed in the existence, in the Angolan language, of the same Latin cases and the articles that define them. He also presented the personal and possessive pronouns, and gave, as well, some cardinal numbers.

Dias also compared Kimbundu to the Portuguese phonetics, such as:

As syllabas, qua, que, qui, quo, quu, pronunciaõ-se como no Portuguez, v.g. Guiria, como. E assim saõ as seguintes, ga, gue, gui, go, gu, ja, je, ji, jo, ju, ya, ye, yi, yo, yu (Dias 1697: 1-2).

[The syllables qua, que, qui, quo, quu, are pronounced as in Portuguese, e.g., Guiria, I eat. And so are the following, ga, gue, gui, go, gu, ja, je, ji, jo, ju, ya, ye, yi, yo, yu.]

10. The Lexicon Capuccinum (1951: col. 93) refers to Catechismus pro regno Matambae, lusitanico, latino et eius regni idiomate (Rome 1661: col. 93) and there is a letter to the secretary of Propaganda Fide where he said that he wrote some catechisms in Kongo Language: "Molti mesi sono presentai V. S. Il. ${ }^{\mathrm{ma}} \mathrm{e} \mathrm{Revu.}{ }^{\mathrm{ma}}$ alcuni Catechismi per i Sacramenti in lingua Conghese, e con la lettera Dedicatoria à lei medesima, jn ordine ad esser presentati à cotesti Eminentissimi per la stampa" (Monte Prandone quoted by Brásio 1952-1988, XII: 314) [Many months ago I have presented your most Illustrious and most Reverend lordship with some catechisms for the Sacraments in Congo language, with dedicatory letter, in order to be submitted for printing]. These two quotations seem to be contradictions because in Matamba the language was the Kimbundu (and not the Kikongo language) and this catechism was the development of the Gentio de Angola and it was written in (Kahenda-Mbaka) Kimbundu.

11. Clement Doke (1961: 11) was not correct when he said that Monte Prandone "included three pages of 'Observationes in legendo idiomate Angollae' in preface", because in the 1661 edition there are 11 "rules", of which 10 exist in the first edition, 1642, and the authorship is either Pacconio and/or Couto. It seems that Doke did not see the editio princeps. 
Em lugar destas particulas Portuguezas, $o, o s, a o, a o s, a \grave{a}$, às, usaõ os Ambundos da vogal $O$, pronunciada quasi guttural, \& sem apices, porque nunca serve de vocativo, como no Portuguez, \& Latim. v.g. Neambi ubana omala opembela yâyê. Deos dá aos homens a sua graça. O exemplo está em $O$, antes de mala, \& em $O$, antes de pembala. O nginganga jaüaba, os Padres saõ bons. O exemplo está em $O$, antes de Nginganga (Dias 1697: 33).

[Instead of these Portuguese particles, o, os, ao, aos, aà, às, the Mbundu use the vowel $O$, pronounced almost gutturally, and without apices because it is never used as the vocative as in Portuguese, and Latin, e.g., Neambi ubana omala opembela yâye, God gives his grace to men. The example is in $O$, before mala, and in $O$, before pembala. $O$ nginganga jaüaba, the Priests are good. The example is in $O$, before Nginganga.]

\section{Influence of Manuel Álvares’ars minor (1573)}

From a quick glance at the contents of Dias' Arte, we get the impression of a clear influence of Manuel Álvares' (1526-1583) De Institutione Grammatica Libri Tres, which was the main Jesuit official Latin grammar book after the final version of the Ratio Studiorum (Álvares 1599). Only once, Dias used ${ }^{12}$ the term "grammatica" [grammar] in the whole work and he used it as a synonym for the correct use of the language, in a prescriptive way: "Advirta-se com tudo que pondo-se hũa destas particulas por outra, naõ muda o sentido; mas he impropriedade do idioma da lingua, \& da grammatica" (Dias 1697: 3) [One should warn, nevertheless, that, putting one of these particles for the other does not change the sense, but it is an impropriety of the idiom and the grammar]. Since the $19^{\text {th }}$ century, the scholars found similarities between Dias' book and the traditional grammars of Latin. For instance, in 1891, Ladislau Batalha (1856-1939) said:

O P. Pedro Dias, trabalhador decidido, fez o mais que se podia fazer com os recursos de que lhe foi possível dispor no seu tempo. O latim era a lingua predominante e a medida do saber de cada um. (...) Pedro Dias obedeceu a esta corrente e referiu as suas observações do kimbundo ás formas e typos latinos. Assim elle imaginou descobrir na lingua de Angola casos, declinações, syntaxe equivalente, gerúndios, etc. Desconhecendo a existencia do ramo agglutinativo e dependencia e filiação que o kimbundo tem relativamente áquelle mesmo ramo a que pretence, não é difficultoso calcular a que erros foi conduzido na sua improba tarefa de conciliar o latim com a lingua de Angola (Batalha 1891: 5-6).

[Father Pedro Dias, a hard worker, made the most of what he could with the resources that were available in his time. Latin was the predominant language and the level of knowledge of everyone. (...) Pedro Dias followed this tendency and reported his observations of the Kimbundu language in accordance with Latin forms and types. So he thought, having found cases, declensions, equivalent syntax, gerunds, etc. in the Angolan language. He was unaware of the existence of the agglutinative stem and the dependence and the affiliation that Kimbundu has relative to the same branch to

12. In the other contexts, he spoke of "Arte" [Art], such as in the title, and "regras" [rules], in order to better speak the language. 
which it belongs. As such, it is not difficult to estimate the errors due to the difficult task of reconciling Latin with the Angolan language.]

Particularly in the second part of his book, in the 16 pages of the Syntax (33-48), Dias stated that he follows the rules of the Latin grammar. He stated explicitly that he treats the general rules, which belong to all languages, including this African language, leaving out the Latin specific rules. He also said that he put the first word of the Latin rule and then the example in Kimbundu, in order to present the specific rule he was talking about:

(...) tratamos sómente das regras geraes, que pertencem a todas as linguas, \& que se podem accõmodar à dos Ambundos, deixando as especiaes da lingua Latina. Porem porei a primeira palavra da regra Latina, \& o exemplo da lingua Angolana, declarando o exemplo da mesma lingua, para que se saiba a palavra, que pertence à regra, de que se trata (Dias 1697: 33).

[...We only treat the general rules, which belong to all languages, and can be accommodated to the Mbundu, leaving the special rules of Latin. But I will present the first word using the Latin rule, and then the example in the Angolan language. Thus, stating the example within the same language that you know and how the rule applies to that word.]

For (Latin) grammar, Dias meant the Jesuit Latin Grammar book or, more explicitly, Manuel Álvares' De Institutione Grammatica Libri Tres. Carlota Rosa (see, e.g., 2010: 4-6;2013: 63-68) exposed the similarity between both grammars and declared, for example, that "a gramática latina de Álvares, sabida de cor, oferecia uma espécie de guia de trabalho de campo. (...) O único preparo destes missionários para levar a cabo a descrição era 'saber gramática'” (Rosa 2010: 6) [Álvares' Latin grammar, known by heart, offered a kind of field work guide. (...) The only training that these missionaries had for language descriptions was the 'grammar knowledge']. Rosa compared various rules between the Álvares 1572 edition and Dias' Arte da Lingua de Angola.

Nevertheless, there were four primary Manuel Álvares' grammars: the ars maior, printed initially in Lisbon in 1572 (it has 249 folios); the ars minor, also printed in Lisbon in 1573 without the explanatory notes, commentaries or scholia (it has only 148 folios); the Italian edition of Orazio Torsellino, S.J. (1545-1599) published in Rome in 1584 with several changes in the structure, the syntactical rules, and annotations or scholia (it has 340 folios); and the edition of António Velez, S.J. (1547-1609) (Évora 1599) from the ars maior, with new scholia and a final lexicon (791 pages).

In effect, the (prescriptive) grammar of Álvares was the main linguistic reference for all Jesuits and they should have known it from memory. As a result, especially amongst the missionaries, the Jesuits would have known the abridged or simplest edition, without the scholia (for more details see, e.g., Kemmler 2013; 2015). Indeed, in the $17^{\text {th }}$ century, it was the shortest version that influenced the majority of the Jesuit pedagogic editions, such as: the Curiosas advertencias da boa grammatica (Lisbon 1643, first edition 1619) by Bartolomeu Rodrigues Chorro (1 $7^{\text {th }}$ century); the Margens da Syntaxe com a construcçam em portugues (Porto 
1627 ) by João Nunes Freire (17 $7^{\text {th }}$ century); or the Explicationes in pracipuam partem totius artis Emmanuelis Alvari (Lisbon 1659) by José Soares (1629-1658).

Comparing Álvares' ars minor and Dias' Arte, the similarities are extraordinary and sometimes Dias started the Kimbundu rule with the same words as Álvares, inclusively in Latin, such as:

Regras do Nominativo. Verbum personale, \&c.

Todo o verbo pessoal nesta lingua tem seu nominativo claro, ou occulto. v.g. Eyè üacolo, eme pêngacolo, vòs estais bem, eu tambem estou bem. O exemplo está no pronome, Eye. \& no pronome Eme, nominativos claros. Também se póde dizer: Eye ücola, nguicola pè: onde está o primeiro nominativo Eye, claro, \& no segundo verbo nguicola, occulto (Dias 1697: 33-34).

[Rules of the Nominative. Personal Verb, etc.

Each personal verb in this language has its nominative clear, or occult, v.g. Eyè üacolo, eme pêngacolo, you are well, I am well too. The example is in the pronoun Eye, and in the pronoun Eme, clearly nominatives. We can also say: Eye ücola, nguicola pè: where the first nominative is, and in the second verb, nguicola, occult].

Verbum personale finiti modi antecedit nominatiuus aperte, vel occulte eiusdem numeri, \& personae (Álvares 1573: 58v).

[The personal verb of finite mood requests before itself nominative clearly or occult, which [must agree] in number and person.]

In particular, the rule of the "propria pagorum" cannot be understood without Álvares' rule:

Propria pagorum

Nesta lingua usaõ das preposições $\mathrm{Bo}, \mathrm{Co}, \mathrm{Mo}$, em lugar das palavras, porque perguntamos: v.g. onde, de donde, para onde, perque parte. Com advertencia que as mesmas preposições se accõmodaõ à reposta de cada hũa destas perguntas conforme a significaçaõ dos verbos: v.g. com os verbos de quietação significaõ, in. Exemplo. Fúla üacâla bobata riae. Pedro está em sua casa, üabichile mo Luanda, passou por Loanda, üatundu conzo, sahio de casa, üay cobata, foi para casa (Dias 1697: 43-44). [Proper names of places

In this language, they use the prepositions $B o, C o, M o$, instead of words, because we ask: e.g., where, of where, to where, by which part. With warning that the same prepositions accommodate themselves to answer each one of these questions, according to the meaning of the verbs, e.g., with the static verbs, they mean 'in'. Example: Fúla üacâla bobata riae, Peter is in his house, üabichile mo Luanda, he went through Luanda, üatundu conzo, he left his house, üay cobata, he came to his house.]

Propria pagorum, castellorum, urbium, primae, uel secundae declinationis ponuntur in genitiuo, post quoduis uerbum, si interrogatio fiat per aduerbium, Vbi. (Álvares 1573: $77 \mathrm{v})$.

[Proper names of places, castles, or cities from the first or second declination are put in genitive after any verb if the question starts with the adverb $u b i$.] 
In the next example, Dias used Álvares' book in order to emphasize the differences between both languages and to specify the Kimbundu idiosyncrasies:

Prima, \& secunda persona, \&c.

A primeira, \& segunda pessoa poem-se claramente, quando diversas pessoas mostraõ contrarios desejos, v.g. Eme ngandala culunda o milonga yâ nzambi, eye cuandala cuilundà, eu guardo os preceitos de Deos, mas tu naõ queres guardalos. O exemplo está nos dous pronomes, Eye \& Eme, postos claramente; porque os agentes mostraõ diversos desejos; porque hum quer \& outro naõ quer. (Dias 1697: 34).

[The first and the second person, etc.

The first and second person are clearly placed, when several people show opposite wishes. For example, Eme ngandala culunda o milonga yâ nzambi, eye cuandala cuilundà, I keep the commandments of God, but you do not want to keep them. The example is in both pronouns, Eye and Eme, placed clearly, because the agents show various desires; because one wants, and the other does not want.]

Prima, \& secunda persona fere non explicantur, nisi cum diuersa studia significamus (Álvares 1573: 58v).

[The first and the second person are not usually explained, except when we want to signify different situations.]

In the following quotation, using the adverb "também" [also], it seems that Dias was referring to Álvares' book:

Aut cum plus significamus, \&c.

Tambem se diz nesta lingua mais do que significamos. v.g. Eye üabeta Fula o cuaba o maxima, Tu levas ventagem a Francisco na bondade. O exemplo está no pronome Eye. As vezes collocaõ o nominativo depois do verbo, v.g. Momaca a amba atu ayari, nesta pratica fallaõ duas pessoas. O exemplo está em atu ayari, nominativo do verbo Amba, posposto (Dias 1697: 34).

[Or when we mean more, etc.

One also says in this language more than we mean, e.g., Eye üabeta Fula o cuaba o maxima, You take advantage of Francisco's goodness. The example is in the pronoun Eye. Sometime they use the nominative after the verb, e.g., Momaca a amba atu ayari, in this conversation are speaking two persons. The example is in atu ayari, nominative of the verb amba, postponed.]

Aut cum plus significamus, quam dicimus: (...)

Tu, innocentior, quam Mettellus? Tu, plus significat, quam uerbum ipsum per se declarat (Álvares 1573: 58v)

[Or when we mean more than we say....

Are you more innocent than Metello? You, signifies more than the verb declares itself.]

As a result, Dias' source could not have been Álvares' editio princeps (1572), with the development of the contents or the scholia to the Latin masters, but the ars minor (1573), which was the shortest or abridged version with mainly Latin rules that the Jesuits would have known by heart. This conclusion does not mean that the rules do not exist in the ars maior; on the contrary, as Rosa (2010: 4-6; 
2013: 63-68) established. It is, however, unlikely that the Jesuit missionaries knew it from memory due to all the extensive folios and scientific explanations or scholia.

\section{Conclusion}

The Arte da Lingua de Angola by Pedro Dias, S.J. (1621/1622-1700; 1697) is the first known systematic grammar book of (Kahenda-Mbaka) Kimbundu, written by a Portuguese missionary in Brazil, and the second printed grammar of any Bantu language. For the $17^{\text {th }}$ century, it testified to the then current and customary use of an African language spoken by Brazilian slaves who originated from West Africa, over a large geographic area not limited to the state of Bahia, and also those in Rio de Janeiro. It is possible that the Society of Jesus had imposed this "language of Angola" as a common language in Brazil for the instruction and the conversion of the Angolan slaves and other Bantu ethnic groups.

Pedro Dias was clearly influenced by Manuel Álvares' De Institutione Grammatica Libri Tres, in particular by his ars minor (1573), which the Jesuits would have known from memory, as well as the first edition of Francesco Pacconio and Couto's Gentio de Angola (1642). However, despite using the contemporary Latin metalanguage, Dias realized the main specificities of Kimbundu and described this Bantu language (or subdialect) in terms of phonology, orthography, morphology and syntax. For example, he understood the absence of certain categories in Kimbundu that existed in Latin, such as declensions and cases, the passive voice, and the morphological distinction of gender, and recognized some prefixes or particles of this African language.

\section{Acknowledgments}

My sincere acknowledgments to the anonymous referees for their very stimulating comments and valuable suggestions, which I have tried to accommodate in the final revision of this paper

\section{References}

Álvares, M. 1572. De institutione grammatica libri tres. Olyssipone: Ioannes Barrerius. http://purl.pt/23043 and http://purl.pt/23121 (National Library of Portugal).

Álvares, M. 1573. De institutione grammatica libri tres. Olyssipone: Ioannes Barrerius.

Álvares, M. 1584. De Institutione grammatica libri tres. Quorum secundus nuper est ad veterum fere Grammaticorum rationem revocatus. Roma: Franciscum Zanettum.

Álvares, M. 1599. De institutione grammatica libri tres. Antonii Vellesii ex eadem Societate Iesu in Eborensi Academia Praefecti studiorum opera aucti \& illustrati. Eborae: Emmanuel de Lyra. http://purl.pt/15052 (National Library of Portugal) and http://cisne.sim.ucm.es/record=b2415366 (Complutense University of Madrid). 
Angenot, J-P., Kempf, C.B. \& Kukanda, V. 2011. 'Arte da Língua de Angola de Pedro Dias (1697) sob o prisma da Dialetologia Kimbundu'. Papia 21,2: 231-252.

Assunção, C. 2011. 'Portuguese missionary work and inter-linguistic contact in the East'. In H. Gonçalves (ed.), Metamorfoses: 25 anos do Departamento de Letras, Artes e Comunicação. Vila Real: Centro de Estudos em Letras, pp. 91-117.

Azevedo, C.M. (dir.). 2000. Dicionário de História Religiosa de Portugal. Vol 1: A-C. Lisboa: Círculo de Leitores \& Centro de Estudos de História Religiosa da Universidade Católica Portuguesa.

Batalha, L. [Estêvão da Silva]. 1891. A Lingua de Angola. Lisbon: Companhia Nacional Editora.

Bonvini, E. 2008. 'Línguas africanas e português falado no Brasil'. In J.L. Fiorin \& M. Petter (eds), África no Brasil: A formação da lingual portuguesa. São Paulo: Editora Contexto, pp. 15-62.

Bonvini, E. 2009. 'Revisiter trois siècles après, ‘Arte da lingua de Angola' de Pedro Dias S.I. - grammaire kimbundu, rédigée au Brésil, mais publiée à Lisbonne en 1697'. In M. Petter \& R.B. Mendes (eds), Proceedings of the Special World Congress of African Linguistics: Exploring the African Language Connection in Americas. São Paulo: Humanitas, pp. 15-45.

Bortolami, G. 2012. 'I Bakongo: Società, tradizioni e cambiamento in Angola'. Doctoral thesis, Università degli Studi di Sassari.

Brásio, A. 1952-1988. Monumenta Missionaria Africana. 15 Vols. Lisbon: Agência Geral do Ultramar (vols. 1-11)/Academia Portuguesa de História (vols. 12-15).

Brásio, A. 1958-1979. Monumenta Missionaria Africana. II Série. 6 Vols. Lisbon: Agência Geral do Ultramar/Academia Portuguesa de História.

Chatelain, H. 1889. Grammatica Elementar do Kimbundu ou Lingua de Angola. Genebra: Typ. de Charles Schuchardt.

Chorro, B.R. 1643. Curiosas advertencias da boa grammatica no compendio \& exposição da Arte do Padre Manoel Alvarez em lingua Portugueza. Lisbon: Antonio Alvarez. http://purl.pt/22249 (National Library of Portugal).

Dias, P. 1697. Arte da Lingua de Angola, oeferecida a Virgem Senhora N. do Rosario, Mãy, e Senhora dos mesmos Pretos. Lisboa: Officina de Miguel Deslandes. http://143.107.31.150/bibliotecaPdf/bibDig_775.pdf (Digital Library of the Institute of Brazilian Studies at the University of São Paulo) and http://www. archive.org/details/artedalinguadean00dias (John Carter Brown Library)

Dias, P. 2013. 'Arte da Língua de Angola'. In C. Rosa (ed.), Uma língua africana no Brasil colônia de Seiscentos: O quimbundo ou língua de Angola na Arte de Pedro Dias, S.J. Rio de Janeiro: 7letras, pp. 130-225.

Doke, C.M. 1954. The Southern Bantu languages. London: Oxford University Press.

Doke, C.M. 1961. 'Early Bantu literature - the age of Brusciotto'. In C.M. Doke and D.T. Cole (eds), Contributions to the History of Bantu Linguistics, Johannesburg: Witwatersrand University Press, pp. 8-26.

Freire, J.N. 1627. Margens da Syntaxe com a construcçam em portugues, posta na interlinea do texto das regras della, pella arte do Padre Manoel Alvares da Companhia de Iesu, pera mayor declaraçm aos estudantes, que começam. 
Porto: João Rodrieguez. http://bdh-rd.bne.es/viewer.vm?id=0000056525 (National Library of Spain).

Homburger, L. 1925. Le groupe Sud-Ouest des langues bantoues: Mission Rohan-Chabot, Tome III, Fasc. 1: linguistique. Paris: Librairie Orientaliste Paul Geuthner.

Kemmler, R. 2013. 'De institvtione grammatica libri tres (Lisboa, 1573): a edição princeps da ars minor de Manuel Álvares'. Revista Portuguesa de Humanidades, Estudos Linguísticos 17,1: 43-58.

Kemmler, R. 2015. 'The First Edition of the ars minor of Manuel Álvares' De institvtione grammatical libri tres (Lisbon, 1573)'. Historiographia Linguistica 42,1: 1-19.

Leite, S. 1938-1950. História da Companhia de Jesus no Brasil. 10 vols. Lisboa: Livraria Portugália (vols. 1-2)/Rio de Janeiro: Civilização Brasileira, (vols. 3-10).

Leite, S. 1940. 'Jesuítas do Brasil, naturais de Angola'. Brotéria, Revista Contemporânea de Cultura 31,3-4: 254-261.

Leite, S. 1947. 'Padre Pedro Dias, autor da Arte da Lingua de Angola, apóstolo dos negros no Brasil (Nota biobibliográfica)'. Portugal em África IV,2: 9-11.

Leite, S. 1965. Suma Histórica da Companhia de Jesus no Brasil (Assistência de Portugal) 1549-1760. Lisbon: Junta de Investigação do Ultramar.

Leite, S. 1993. Breve História da Companhia de Jesus no Brasil - 1549-1760. Braga: Livraria Apostolado da Imprensa.

Levi, J.A. 2009. 'Portuguese and other European missionaries in Africa: A look at their linguistic production and attitudes (1415-1885)'. Historiographia Linguistica 36,2/3: 363-392.

Lewis, M.P., Simons, G.F. \& Fennig, C.D. (eds) 2014. Ethnologue: Languages of the World. Seventeenth edition. Dallas, Texas: SIL International. http://www. ethnologue.com/language/kmb (last access: December 16, 2014).

Lexicon Capuccinum. Promptuarium historico-bibliographicum ordinis Fratrum Minorum Capuccinorum, 1525-1950. 1951. Rome: Bibliotheca Collegii internationalis S. Laurentii Brundusini.

Livingstone, D. 1984 [1857]. Missionary Travels and Researches in South Africa: Including a Sketch of Sixteen Years' Residence in the Interior of Africa. London: John Murray, Albemarle Street.

Maho, J.F. 2009. BOB Online (Bantu Online Bibliography). http://goto.glocalnet. net/jfmaho/bob.pdf (last access: January 8, 2015).

Pacconio, F. \& do Couto, A. 1642. Gentio de Angola sufficientemente instruido nos mysterios de nossa sancta Fé. Obra posthuma, composta pello Padre Francisco Pacconio da Companhia de Iesu. Redusida a methodo mais breve \& accomodado á capacidade dos sogeitos, que se instruem pello Padre Antonio do Couto da mesma Companhia. Lisbon: Domingos Lopes Rosa.

Pacconio, F. \& A. Maria de Monte Prandone, A. 1661. Gentilis Angollae fidei mysteriis Lusitano olim idiomate per R. P. Antonium de Coucto Soc. Iesv Theologum; nunc autem Latino per Fr. Antonivm Mariam Prandomontanum, Concionatorem Capucinum, Admod. Rev. Patris Procuratoris Generalis Comissarij Socium, Instructus, atque locupletatus. Rome: Typis S. Congreg. de Propaganda Fide. 
Rodrigues, F. 1931-1950. História da Companhia de Jesus na Assistência de Portugal. 4 tomes in 7 vols. Porto: Livraria Apostolado da Imprensa.

Rosa, M.C. 2006. 'Revendo uma das críticas às descrições missionárias'. Revista de Estudos da Linguagem 14,1: 203-230.

Rosa, M.C. 2010. 'A Arte da língua de Angola (1697) e a gramática latina de Manuel Álvares (1572)'. Eutomia: Revista Online de Literatura e Linguística, Year III,2: 1-7. http://www.revistaeutomia.com.br/volumes/Ano3-Volume2/ especial-destaques/destaques-linguistica/destaque_a_arte_da_lingua_de_ angola.pdf (last access: December 31, 2014).

Rosa, M.C. 2011. 'Uma gramática jesuíta seiscentista: a Arte da Língua de Angola', REDE-A Revista de Estudos Afro-Americanos 1,1: 141-200. http://www.revista. universo.edu.br/index.php?journal $=4$ revistaafroamericanas $4 \&$ page=article \&op =view\&path $\% 5 B \% 5 \mathrm{D}=460$ (last access: December 31, 2014).

Rosa, M.C. 2013. Uma língua africana no Brasil colônia de Seiscentos: O quimbundo ou língua de Angola na Arte de Pedro Dias, S.J. Rio de Janeiro: 7letras.

Soares, J. 1659. Explicationes in proecipuam partem totius artis Emmanuelis Alvari quce syntaxim complectitur. Ulyssipone: António Craesbeeck.

Streit, R. \& Dindinger, J. (eds) 1952. Bibliotheca Missionum. XVI. Band: Afrikanische Missionsliteratur 1600-1699. Freiburg: Herder.

Vetralla, G.B. 1659. Regulae quaedam pro difficillimi Congensium idiomatis faciliori captu ad grammaticae normam redactae a F. Hyacintho Brusciotto a Vetralla Concionatore Capuccino Regni Congi Apostolicae Missionis Praefecto. Rome: Typis Sacra Congregatio de Propaganda Fide.

Zwartjes, O. 2009. 'Tiempo y aspecto verbal en las primeras gramáticas de lenguas bantúes de las misiones católicas (siglos XVII-XVIII)'. Revista Internacional de Lingüística Iberoamericana VII 1,13: 233-261.

Zwartjes, O. 2011. Portuguese Missionary Grammars in Asia, Africa and Brazil, 1550-1800. Amsterdam/Philadelphia: John Benjamins.

\section{Author's address}

Gonçalo Fernandes

Universidade de Trás-os-Montes e Alto Douro

Quinta de Prados

5001-801 Vila Real

Portugal

gf@utad.pt

\section{Résumé}

Pedro Dias, S.J. (1621/1622-1700) a publié la première grammaire connue du kimbundu, sous le titre Arte da Lingua de Angola, oeferecida (sic) a Virgem Senhora N[ossa] do Rosario, Mãy, e Senhora dos mesmos Pretos (Lisbonne 1697) [Grammaire de la langue de l'Angola, dédiée à Notre-Dame du Rosaire,Mère et Dame des Noirs], à l'usage des missionnaires jésuites, particulièrement ceux du Nord-Est du Brésil, pour instruire et convertir les nombreux esclaves angolais et 
les autres esclaves bantu d'Afrique occidentale qui y vivaient. Cet article décrit la pertinence de la grammaire de Dias dans l'historiographie portugaise, brésilienne et angolaise. En dépit de sa petite taille (pas plus de 48 pages) et bien qu'il soit dépourvu d'explication théorique, L'Arte de Dias est un ouvrage pionnier en matière de linguistique bantu, puisqu'il s'agit de la première grammaire systématique connue du kimbundu (de Kahenda-Mbaka) tel qu'utilisé en langue générale ou commune à Bahia et à Rio de Janeiro (Brésil) au XVII ${ }^{\mathrm{e}}$ siècle, et de la deuxième grammaire imprimée d'une langue bantu, précédée par la seule Regulae quaedam pro difficillimi Congensium idiomatis facilioricaptu ad grammaticae normam (Rome 1659) [Règles pour une compréhension plus facile de la langue la plus difficile des Congolais, rédigées à la façon d'une grammaire]. Cet article démontre également que l'Arte da Lingua de Angola, en plus de suivre le catéchisme de Pacconio et Couto (1642), est basé sur l'ars minor de Manuel Álvares (Lisbonne 1573) en dépit de l'ars maior de celui-ci (Lisbonne 1572). 